\title{
INTEGRAL APROACH TO ENTERPRISE CULTURE AS ONE OF THE ENTERPRISES' KEY SUCCESS FACTORS
}

\author{
Borut Milfelner* Jernej Belak ${ }^{\dagger}$
}

Keywords: Integral management, Customer oriented business culture, Employee oriented business culture, Enterprise Performance, Enterprise key success factors.

JEL: M12, M14, M31

\begin{abstract}
Enterprise culture is judged by many acknowledged scientists and researchers now as a major determinant of any enterprise's success. The present article shows the research cognitions on the impact of enterprise culture to the success of the enterprises observed. It investigates the impact of customer and employee oriented enterprise culture on market and financial performance of the enterprise. Results suggest that enterprises, which are more customer (externally) oriented, show better market performance as well as better financial performance. The cognitions also show that more employee (internally) oriented enterprises, show positive impact to their market as well as to their financial performance.
\end{abstract}

*Assistant Professor at Faculty of Economics and Business Maribor; tel:+38622290235, fax: +386222 90217; e-mail: borut.milfelner@uni-mb.si, Razlagova 14, 2000 Maribor, Slovenia

†Assistant Professor at Faculty of Economics and Business Maribor; tel: +38622290280 , fax: +386222 90217; e-mail: jernej.belak@uni-mb.si, Razlagova 14, 2000 Maribor, Slovenia

Borut Milfelner, Jernej Belak - INTEGRAL APROACH TO ENTERPRISE CULTURE AS ONE OF THE ENTERPRISES' KEY SUCCESS FACTORS 


\section{Introduction}

Enterprise culture is judged by many now as a major determinant of any company's success in terms of performance, especially through improvements in employee morale (Igo and Skitmore, 2006). Various researches show that enterprise culture with its values is of essential meaning by fostering business ethics in a sense of assuring enterprise's success (e.g. Belak and Milfelner, 2011; Belak et al., 2010; Belak and Mulej, 2009). Hofstede (1998a, 1998b) argues that enterprise culture as the collective programming of the mind distinguishes participants of one enterprise from another. Such collective programming is possible if enterprise culture is considered as basic assumptions that people in an enterprise hold and share about that enterprise. Those assumptions are implied in their shared feelings, beliefs and values and embodied in symbols, processes, forms and some aspects of patterned group behavior. Further Hofstede (1998a, 2000) argues that enterprise culture distinct from both individual personality (one person) and human nature (all humans).

Considering the theories and research cognitions presented in this paper, we can state that organizational culture with its values and norms is of essential meaning for ensuring the long term success of an enterprise. Enterprise's culture has been defined as encompassing values, rules, beliefs and assumptions in handling and behaviour of (especially internal) enterprise's stakeholders which reflects internally as well externally the behaviour of an enterprise. Besides other relevant scientific literature and research cognitions, as well as world known models of enterprise management and governance, enterprise culture is perceived as one of the enterprise's key success factors in MER Model of Integral Management developed by the Institute for Management and Development (MER) in Slovenia (Belak, 2010). Considering MER Model of Integral Management (Belak, 2010) selected enterprise's key success factors are as follows: compatibility, competitiveness, efficiency, culture, credibility, ethics, ecology, entrepreneurship, synergy, and philosophy.

On the basis of MER Model of Integral Management (Belak, 2010) several researches were carried out to examine enterprise core values, culture and ethical 
climate (considered as constitutional elements of enterprise ethical behaviour by MER Model of Integral Management) in relation to enterprise success.

In their research Belak et al. (2010) argued that in order to achieve the optimal effectiveness level of business by ethical behaviour, the initiated measures of business ethics should never be implemented as isolated tools, but only in the frame of a full and complete ethics program. The initiated business ethics measures have to be correctly adjusted and coordinated, as well as integrated, in a common business ethics concept, program or plan. An enterprise's top management can be considered as the "agent" responsible for harmonization of stakeholders' interests (as well as different cultures); therefore we argue that formulation and implementation of an ethics program strongly depend on top management. In our opinion, the top management can also be considered as the executor of the enterprise's culture (values and norms initiated by the enterprise owners), which represents one of the most important elements in the context of an enterprise's ethical behaviour.

For successful implementation of the ethics program or plan, it is important that it is internalized by all (especially internal) stakeholders within the enterprise (owners, managers on all management levels, experts and all other coworkers). We have shown that credibility and ethical behaviour of an enterprise can be achieved only through requisitely holistic enterprise planning (Belak et al., 2010). It should be implemented from top to bottom, starting with the enterprise owners' values that influence enterprise's vision and enterprise's policy (Thommen, 2003) and to the fundamental (basic) - realization process and in all of its own pore incorporated also in enterprise environment. One of the important authors' (Belak et al., 2010) argumentation is also that the proposed concept of the requisitely holistic planning of constitutional elements and implementation measures of enterprise ethics has a major impact to the environment of an enterprise functioning and vice versa.

Following the above described theoretical background Duh et al. (2010) carried out research, which examined the association between the degree of family involvement in an enterprise and its influence on the enterprise's core values, culture and ethical climate as the constitutional elements of enterprise ethical 
behaviour. The research demonstrated that the majority of the enterprises examined have a positive attitude towards core values related to ethical content. These research cognitions indicate that the key stakeholders of the examined enterprises are aware of the importance of the ethical core values and of the fact that - without such a positive attitude - the ethical behaviour of the enterprise or the credible status of the enterprise at the market is impossible. Therefore, the key stakeholders of the examined enterprises link their positive attitude towards ethical core values with the success of the enterprises. The research revealed no significant differences between family and nonfamily enterprises. Such research cognitions can be supported also by the research carried out by Duh and Belak (2009).

In regard to the type of enterprise culture, the research results (Duh et al., 2010) demonstrated a stronger presence of clan culture characteristics in family than in nonfamily enterprises. In other words, family enterprises are more personal, in which employees act and feel like part of the family; leadership is considered to be mentoring. The management in the enterprises observed was characterized by teamwork and participation; employees showed a high level of mutual trust and commitment to their enterprises. The studied family enterprises emphasized human development, trust and openness.

Since the research results (Duh et al., 2010) show a stronger presence of hierarchical and market culture characteristics in non-family enterprises (albeit not at statistically significant levels in the case of hierarchical culture), non-family enterprises appeared to be more dynamic in the entrepreneurial sense: People are willing to take higher risks, are more competitive, and are achievement oriented. Although a high degree of 'care for people' is present in non-family enterprises, these enterprises showed a strong tendency for innovation and risk taking, market aggression and orientation towards results. The management in these enterprises expressed high demands and achievements. The research findings indicate that people in these enterprises trusted one another, but based on their significant commitment to innovation and goal accomplishment. Therefore, new challenges and prospects for new opportunities in these enterprises are very important. According to their desire for success, their primary goal is the domi- 
nation at the marketplace. The results also point to a stronger culture in family businesses than in non-family ones. Although the difference is not statistically significant, the results are very similar to those of Vallejo (2008), demonstrating that in family businesses the level of Core Values, Culture and Ethical Climate adoption and acceptation of the values and norms is higher. Furthermore, the level of compatibility of values and norms within the examined enterprises (e.g. between various departments) as well as the level of compatibility of values and norms between enterprises and the environment of their functioning is higher in family businesses than in non-family ones.

The results (Duh et al., 2010) also highlighted that family enterprises are more caring than non-family ones; indeed, the characteristics of the caring climate are more present. As expected, the characteristics of the independence climate are also more present in family than in nonfamily enterprises. However, the law and code climate characteristics are unexpectedly more evident in family than in non-family enterprises. These research results in regard to ethical climate concur with Victor and Cullen's (1988) argument that climates in organizations reflect in part institutionalized societal norms. In other words, according to their research results, the presence of the caring climate implies that societal norms require organizations to develop at least a minimal caring environment. However, the results indicate that a caring climate is much more present in family than in non-family businesses, which suggests that benevolence (utilitarianism) prevails in family businesses. In a benevolent climate, the expectation is that members of the organization are concerned with the well-being of each other both within and outside the organization. The group process characteristics typical of a benevolent climate may establish a positive affective tone among organizational members, which may result in behaviours such as the spreading goodwill and good information about the organization and protecting the organization against threats to its proper functioning, which are indicative of higher commitment (Cullen et al., 2003). The prevailing benevolent climate in family businesses could be thus be explained as well with the presence of middle-tostrong organizational culture to a greater extent than in non-family business, where businesses with weak culture were also found (although differences were 
not statistically significant).

Considering the research cognitions (Duh et al., 2010) we can conclude that some differences in ethical core values, climate and culture exist between family and non-family enterprises. As such, we argue that the functioning of nonfamily enterprises indicates a lower level of connection among co-workers, top management, and employees as well as less loyalty, anchoring of enterprise values and norms, and capacity for innovative behaviour, which can be considered one of the key success factors in business. Our research raises important issues regarding nonfamily enterprises' high level of hierarchical culture. Such enterprises are neither able to tolerate differences among employees or stakeholders nor are prepared to stimulate or use individuals' talents in accordance with the enterprises' visions, missions and policies. The alienation between top management and employees can have an important further implication, such as alienation between the enterprise and its environment, which can make the enterprise incapable of efficiency and effectiveness. Thus, these enterprises should implement all measures - informal as well as formal - of business ethics to foster, support, and transform the ethical core values in the higher presence of the clan culture and caring climate characteristics and achieve consistency among mission, vision, enterprise values and culture, which is of essential meaning for enterprise's long run success.

In their research Belak and Mulej (2009) revealed some differences in enterprise ethical climate per enterprise life cycle stages. The research indicated movement towards a more and more bureaucratic method of enterprise functioning, as an enterprise moves from the pioneer stage towards the stage of turn-over. This pattern of functioning can also indicate a lower level of connection between co-workers, top-management and employees, as well as less loyalty, anchoring of enterprise values and norms, and capacity for innovative behaviour, which can be considered as one of the key success factors in business. Our research (Belak and Mulej, 2009) raises important issues regarding the enterprises in mature stage or turn-over stage, which are neither able to tolerate differences among employees as well as between all stakeholders nor prepared to stimulate or use the individuals' talents in accordance with the enterprises' visions, missions and 
policies. The alienation between top management and employees can have an important further implication such as alienation between the enterprise and its environment, which can make enterprise incapable of efficiency and effectiveness. The basis for creative work is trust among employees. Furthermore, by various authors trust is considered as the constitutional element of enterprise's ethical behaviour and constitutional basis for enterprise's ethical climate (Victor and Cullen, 1988; Kaptein, 1998). The above-mentioned enterprises should therefore implement all measures, institutional as well as structural, which would foster and support trust in their enterprises. Thus, the climate can provide for innovative behaviour.

The research cognitions about the enterprise climate type (Belak and Mulej, 2009) can be supported also by the research cognitions about the enterprise culture type (Belak, 2009). Those research findings show that, through the life cycle stages, enterprises make a transition from a "clan" culture, where a very personal and familiar way of functioning can be observed, towards a "hierarchy" culture, where formal structures and procedures are in focus. Besides, the dependency of an enterprise's culture type on its life cycle stage, the research indicated that the culture strength depends on the life cycle stage, as well. In the enterprise life cycle transition (from pioneer enterprise towards the enterprise in turn-over), the culture strength changes from strong towards weak, as well. The research results showed that pioneer and growing enterprises are more successful in implementing the enterprise's norms, values, vision, mission and strategic goals through the entire management and governance process (from the owners through the top and middle management to the operational level of the enterprise) than are mature enterprises and enterprises in turn-over. These results also reveal that the pioneer and growth enterprise culture is more compatible with the culture of the environment where they function than the culture in mature enterprises and enterprises in turn-over.

In a frame of business culture Belak and Milfelner (2011) carried out the research on Culture as Enterprise's Key Success Factor, which showed that enterprises, which are more customer (externally) oriented, show better market performance as well as better financial performance. The cognitions also show that more em- 
ployee (internally) oriented enterprises, show positive impact to their market as well as to their financial performance. These cognitions also partly confirm the theoretical argument that enterprise long term success can be ensured only by practicing the external (effectiveness) as well as internal (efficiency) orientation of enterprise, both together.

The research cognitions (Belak and Milfelner, 2011) on informal and formal institutional measure of business ethics implementation (in relation to enterprise life cycle) revealed only one statistically significant difference regarding informal and formal measures of business ethics implementation, which is manager concern/role-modelling. The role-modelling is present more greatly in the pioneer and growing enterprises than in the mature enterprises and enterprises in turn over.

Despite this fact, as regards the informal institutional measures of business ethics implementation, the research (Belak and Milfelner, 2011) has shown that manager role-modelling and reward systems based on ethical standards are to some extent more present in enterprises in early (pioneer and growing) life cycle stages than in enterprises in late (mature and turn over) life cycle stages. As regards the role-modelling, the results are understandable since the demonstration of ethical behaviour by the management is above all important in early phases of organizational culture creation. In that phase, enterprises are usually smaller and the contacts between employees and management are more frequent. In addition, we can assume that there is a general lack of material for stories about ethical or unethical behaviours of employees. Higher revenues in the growing phase of the life cycle enable management to develop adequate reward systems to stimulate the desired ethical behaviour.

Candid ethical communication on the other hand is most frequent in enterprises in the mature life cycle stage. Such enterprises more often use communication of stories about ethical or unethical employees in order to foster ethical behaviour. The last two measures are very important since they can both be placed under the concept of corporate culture.

Concerning the formal institutional measures of business ethics implementation, a mission statement is mostly present in growing and mature enterprises and 
only quite rarely in pioneer enterprises. This finding is to some extent surprising, since one would expect that smaller enterprises in pioneer life cycle would also have a clear vision and mission, which would enable them to clarify and develop proper objectives. Concerning compliance manual development, research results also showed that the vast majority of companies in Slovenia, especially those in late life cycle stages, are not well acquainted with ethical standards. This is above all true for European ethical standards.

Ethical behavior, ethical climate and informal and formal measures are important predecessors of enterprise culture and various lessons for managers can be learned from above described studies how to implement the needed cultural elements. However less is known about how cultural elements impact enterprise performance in developing industries and if enterprises with higher presence of different cultural elements are in fact more successful. The present research is based on the premise that by ensuring their success the enterprises have to be oriented towards the external environment of its functioning as well as towards the internal environment of its functioning in order to be able to disclose and fulfill the real needs of the environment (market) and to realize and fulfill the needs of the employees (as well as other internal stakeholders) in order to motivate and stimulate their innovative behavior as much as possible. Only this way the long term success of the enterprise will be assured.

\section{HYPOTHESIS DEVELOPMENT}

Enterprise/corporate culture is a multifaceted construct. Various authors define it differently. Huczynski and Buchanan (2007) focused on the observed behavioral regularities in people's interactions, Huczynski and Buchanan (2007) discussed the norms that evolve in working groups, Ouchi (1981) stressed the philosophy that influences organizational policy and Huczynski and Buchanan (2007) emphasized the rules for good understanding in an organization. More recently, enterprise/corporate culture has been defined as encompassing the assumptions, beliefs, goals, knowledge and values that are shared by organizational members (e.g. Belak, 2009; Deal and Kennedy, 1982; Huczynski and Buchanan, 
2007).

Various types of enterprise/corporate cultures have been identified - related to the dynamic nature of the industry concerned (Gray et al., 2003) and to the size of the organization (Gray et al., 2003). Several classifications have been proposed, the most often cited being those of Schwartz and Davis (1981), Deal and Kennedy (1982), Hofstede (1990, 2000), Schein (1983, 1992), Sathe (1984) and Cameron and Quinn (1999). Hofstede (1983) proposed that enterprise culture could be classified by comparing the degree of individualism versus collectivism, the apparent power-distance metric, the tendency towards uncertainty avoidance, and the bias between masculinity and femininity. De Vries (1993), on the other hand, opted to derive his classification from characteristics of the prevailing mentality: a paranoid culture (a persecutory theme), an avoidance culture (a pervasive sense of futility), a charismatic culture (everything evolves around the leader), a bureaucratic culture (depersonalized and rigid), politicized culture (leadership responsibility is abdicated).

In Thommen's (2003) opinion, an enterprise should emphasize its culture as much as to bring it into accordance with the enterprise's vision and strategy. Thommen (43) differentiates between strong and weak enterprise cultures. An enterprise with a strong culture is the one with a high level of values and highnorms anchoring, a high level of agreement, as well as high-culture compatibility between enterprise and the environment of its functioning.

More recently, Cameron and Quinn (1999) have proposed a classification comprising four forms for culture audit and for comparison purposes - Clan, Hierarchy, Market and Adhocracy. Following the methodology developed by Cameron and Quinn (1999), these culture types can be assessed by observing the six key dimensions of enterprise culture: Dominant Characteristics, Organizational Leadership, Management of Employees, Organizational Glue, Strategic Emphasis, and Criteria for Success.

Webster (1995) defines market culture as the component of enterprise culture that relates to values and beliefs that help management and employees to understand market. It sets norms of behaviour in the enterprise and the meaning that is vital for enterprise performance on the market. As such market cul- 
ture relates to the unwritten policies and guidelines which provide employees with behavioural norms, to the importance the enterprise as a whole places on the marketing function, and to the manner in which marketing activities are executed.

As a business philosophy, market oriented enterprise culture is an entity of three key elements. According to Narver and Slater (1990) the enterprises with strong elements of customer oriented culture demonstrate high customer and competitor orientation, and have the ability of interfunctional cooperation. Customer orientation is the key component of market culture which enables managers and employees to understand customer needs and wants as well as customer present and future product value evaluation. Competitor orientation on the other side brings understanding of short term competitor strengths and weaknesses and long term competitor strategies. This component is also important, since competitor strategies can strongly influence customer wants and needs, their value perceptions as well as their behaviour. The third component (interfunctional coordination) relates to customer information interchange throughout the enterprise and to coordination of efforts oriented towards customers. The third component is the most culture related and is also the most difficult to achieve. Customer oriented culture of an enterprise should enhance customer-perceived quality by helping to create and maintain superior customer value. Enterprises with strong customer orientation possess the basis for rapid adaptation to customers' manifest and latent needs, which may translate into superior new product success, market share and profitability (Baker and Sinkula, 2005; Narver et al., 2004). The customer oriented enterprise culture has been proposed as a key differentiating resource and a key predictor of enterprise performance (Atuahene-Gima et al., 2005). According to that we hypothesize:

H1: The presence of customer oriented enterprise culture positively impacts market performance of enterprise.

H2: The presence of customer oriented enterprise culture positively impacts financial performance of enterprise.

By drawing the analogy with customer oriented enterprise culture, employee elements can also define the kind of culture that stimulates the application of 
marketing, human resource management, and allied theories, techniques, and principles to motivate, mobilize, and manage internal stakeholders at all hierarchical levels of the enterprise's process of management and governance to continuously improve the way they serve external stakeholders and each other. Although some early authors have referred to enterprise's internal stakeholders activities as the one that treats employees of the enterprises as internal customers (Berry, 1981), it is reasonable to argue that the cultural view is more suitable to explain in what way satisfied internal stakeholders (employees) can contribute to higher enterprise's performance. Such culture or behaviour as a result of culture is in literature frequently defined as enterprise's internal market orientation (e.g. Lings and Greenley, 2009, Gounaris, 2006). According to Lings (2004) activities resulting from employee oriented enterprise culture incorporate cultural and behavioural dimension and are referred to as internal market orientation in the sense of identifying and satisfying the wants and needs of employees as a prerequisite to satisfying the wants and needs of external customers. Such internal market oriented behaviour displayed by managers should foster employee identification with the organisation, reduce their dysfunctional behaviours and increase behaviours that are compliant with organisational strategies (32).

In the sense of Narver and Slater's (1990) and Kohli and Jaworsky's (1990) internally oriented enterprise culture can be operationalized as enterprise's orientation on: employees, competitors (on the employee market), and as interfunctional coordination on internal market. Measurement of those three dimensions shows the presence of the employee oriented enterprise culture. Each of these elements contain: internal market intelligence generation (e.g. conditions of external employee market, identification of value exchange), internal market intelligence dissemination (between employees and management) and internal market responsiveness (e.g. actions for delivering employee value).

Since the internally oriented enterprise culture can build a system of employee and management values that guide the enterprise's behaviour towards the goal of improving customer value such culture can also influence market and financial performance of the enterprise in the sense of being related with higher exter- 
nal customer quality perception, external customer satisfaction, market shares and sales volume. All four market performance dimensions can be influenced by employee attitudes and behaviours that reduce dysfunctional behaviours and increases behaviours compliant with organisational strategies (Lings and Greenley, 2009). Consequently we hypothesise that:

H3: The presence of employee oriented enterprise culture positively impacts market performance of enterprise.

H4: The presence of employee oriented enterprise culture positively impacts financial performance of enterprise.

\section{METHODOLOGY}

Measurement instrument for the empirical model verification was developed in three phases. In the first phase some of the relevant items for the questionnaire were taken from the relevant literature. For the measurement of employee oriented culture we used adapted items from Gounaris (2006) and Lings (2004). The questions were adapted in the way that the cultural elements could be captured in the larger scale. Customer oriented culture was measured using the fourteen adapted items from Narver and Slater's (Narver and Slater, 1990) scale. Some additional items were added in order to ensure higher consistency of the measure. In the second phase, in-depth interviews were conducted with senior marketing executives in 17 enterprises in Slovenia. In the third phase the questionnaire was examined by 5 expert judges ( 4 in the field of marketing and marketing resources and 1 in the field of finance) in terms of content validity and in order to avoid redundancy of the questions. In the final study the items for employee oriented culture (12) and customer oriented culture (17) were measured on the 7 point Likert scale (from 1 "strongly disagree" to 7 "strongly agree"). Additional 4 items were generated for measurement of market performance. The respondents were asked to evaluate their market performance on the 7 point scale from "much worse" to "much better" in comparison with their key competitors in the period of past 3 years.

The main informants were selected from every company in the position of CEO 
or member of the Board of Directors. The questionnaire was mailed to the 3000 randomly selected companies with more than 20 employees, selected from the population of 3475 companies in Slovenia with more than 20 employees. The final sample consisted of 415 companies, representing a response rate of $13.8 \%$, which is rather low. This can be attributed due to the length of questionnaire, which besides the scales for measurement of customer oriented business culture, employee oriented business culture, market and financial performance also included additional scales which were not a subject of this research and was altogether 11 pages long. The second reason for low response might be the fact that this study was conducted on organizational level where top managers were the main informants. Still there is clear evidence in the literature that such studies with lower response rates are representative and may be published (Werner et al., 2007).

Responding companies came from a variety of industries (manufacturing 40.8\%, construction $13.2 \%$, wholesale and retail $11.0 \%$, real estate $10.0 \%$, transportation $5.1 \%$, catering industry $4.9 \%$, and other industries $14.7 \%$ ).

Dimensionality of the single constructs (customer oriented business culture, employee oriented business culture, customer loyalty, market share/sales volume, and financial performance) was assessed. Confirmatory factor analyses

\section{CONSTRUCT RELIABILITY AND VALID- ITY}

The dimensionality of the single constructs (customer oriented business culture, employee oriented business culture, customer loyalty, market and financial performance) was assessed with confirmatory factor analyses (CFA). Summary statistics in Table 1 show that according to our conceptualization customers and employee oriented business culture constructs are multi-dimensional constructs. 
TABLE 1- Statistics of CFA for customer and employee oriented business culture, market, and financial performance

\begin{tabular}{llll}
\hline \hline & $\begin{array}{l}\text { Customer oriented } \\
\text { business culture }\end{array}$ & $\begin{array}{l}\text { Employee oriented } \\
\text { business culture }\end{array}$ & $\begin{array}{l}\text { Market and financial } \\
\text { performance CFA }\end{array}$ \\
\hline $\begin{array}{l}\text { One-factor } \\
\text { model }\end{array}$ & 1 factor & $\begin{array}{l}1 \text { factor } \\
\chi^{2} / \mathrm{df}=300.55 / 20\end{array}$ & $\begin{array}{l}\chi^{2} / \mathrm{df}=432.90 / 44 \\
\mathrm{p}<0.05\end{array}$ \\
& $\mathrm{p}<.05$ & $\mathrm{RMSEA}=.164$ & \\
& $\mathrm{RMSEA}=.184$ & $\mathrm{NNFI}=.682$ & \\
& $\mathrm{NNFI}=.696$ & $\mathrm{CFI}=.746$ & \\
& $\mathrm{CFI}=.783$ & $\mathrm{GFI}=.805$ & \\
& $\mathrm{GFI}=.777$ & 3 factors $* *$ & 2 factors \\
Multi-factor & 3 factors $*$ & $\chi^{2} / \mathrm{df}=34.36 / 24$ & $\chi^{2} / \mathrm{df}=32.68 / 8$ \\
model & $\chi^{2} / \mathrm{df}=18.16 / 17$ & $\mathrm{p}=.078$ & $\mathrm{p}>05$ \\
& $\mathrm{p}=.378$ & $\mathrm{RMSEA}=.032$ & $\mathrm{RMSEA}=.086$ \\
& $\mathrm{RMSEA}=.013$ & $\mathrm{NNFI}=.977$ & $\mathrm{NNFI}=.955$ \\
& $\mathrm{NNFI}=.990$ & $\mathrm{CFI}=.985$ & $\mathrm{CFI}=.976$ \\
& $\mathrm{CFI}=.994$ & $\mathrm{GFI}=.978$ & $\mathrm{GFI}=.973$ \\
\hline \hline
\end{tabular}

Source: Authors Calculation

* Customer oriented business culture - employees orientation, competitors (on the employee market) orientation, and interfunctional coordination ** Employee oriented business culture - customer orientation, competitor orientation, and interfunctional coordination

The reliability (table 2) coefficient of the scales ranges from .76 to .91 which met the standard of 0.6 as suggested by Fornell and Larcker (1981). Evidence of convergent validity was determined by inspection of the variance extracted for each factor as shown in Table 3. According to Fornell and Larcker (1981), convergent validity is established if the variance extracted value exceeds 0.50 for a factor, and for all of the cases this criteria is meet. 
TABLE 2- Items, standardized loadings, CR and AVE

\begin{tabular}{|c|c|c|c|c|}
\hline & & $\begin{array}{l}\text { Loadings }(\lambda \\
\text { coefficients) }\end{array}$ & $\mathbf{C R}$ & AVE \\
\hline \multirow[t]{3}{*}{$\begin{array}{l}\text { Customer oriented business } \\
\text { culture - Customer orientation }\end{array}$} & $\begin{array}{l}\text { We closely monitor and assess our } \\
\text { level of commitment in serving } \\
\text { customers' needs. }\end{array}$ & .826 & .76 & .52 \\
\hline & $\begin{array}{l}\text { We pay close attention to after-sales } \\
\text { service. }\end{array}$ & .549 & & \\
\hline & $\begin{array}{l}\text { Our strategy for competitive } \\
\text { advantage is based on our } \\
\text { understanding of customers' needs }\end{array}$ & .765 & & \\
\hline \multirow{3}{*}{$\begin{array}{l}\text { Customer oriented business } \\
\text { culture - Interfunctional } \\
\text { coordination }\end{array}$} & $\begin{array}{l}\text { Market information is shared with } \\
\text { all departments. }\end{array}$ & .834 & .79 & .55 \\
\hline & $\begin{array}{l}\text { All departments are involved in } \\
\text { preparing business plans/strategies. }\end{array}$ & .763 & & \\
\hline & $\begin{array}{l}\text { Information about customers is } \\
\text { freely communicated throughout our } \\
\text { organization }\end{array}$ & .593 & & \\
\hline \multirow[t]{3}{*}{$\begin{array}{l}\text { Customer oriented business } \\
\text { culture - Competitor orientation }\end{array}$} & $\begin{array}{l}\text { We respond rapidly to competitive } \\
\text { actions. }\end{array}$ & .734 & .80 & .56 \\
\hline & $\begin{array}{l}\text { Top management regularly discuss } \\
\text { competitors' strength and } \\
\text { weaknesses. }\end{array}$ & .780 & & \\
\hline & $\begin{array}{l}\text { We regularly monitor our } \\
\text { competitors' marketing efforts. }\end{array}$ & .739 & & \\
\hline \multirow[t]{3}{*}{$\begin{array}{l}\text { Employee oriented business } \\
\text { culture - Employee orientation }\end{array}$} & $\begin{array}{l}\text { We aspire to high employee } \\
\text { satisfaction. }\end{array}$ & .871 & .89 & .72 \\
\hline & $\begin{array}{l}\text { The appreciation of the single } \\
\text { employee is stressed strongly. }\end{array}$ & .798 & & \\
\hline & $\begin{array}{l}\text { We place great value on a feeling of } \\
\text { belonging along the employees. }\end{array}$ & .881 & & \\
\hline \multirow{3}{*}{$\begin{array}{l}\text { Employee oriented business } \\
\text { culture - Competitor } \\
\text { orientation (on the employee } \\
\text { market) }\end{array}$} & $\begin{array}{l}\text { We systematically analyze the } \\
\text { working conditions of employees } \\
\text { working in competition. }\end{array}$ & .639 & .81 & .59 \\
\hline & $\begin{array}{l}\text { We know the danger of losing our } \\
\text { employees because of our } \\
\text { competitors. }\end{array}$ & .835 & & \\
\hline & $\begin{array}{l}\text { We know about new jobs created } \\
\text { that could attract employees in this } \\
\text { firm. }\end{array}$ & .776 & & \\
\hline \multirow[t]{2}{*}{$\begin{array}{l}\text { Employee oriented business } \\
\text { culture - Interfunctional } \\
\text { coordination }\end{array}$} & $\begin{array}{l}\text { In our company, we place great } \\
\text { value on interfunctional teamwork. } \\
\text { (marketing, R\&D, production, etc,). }\end{array}$ & .893 & .89 & .80 \\
\hline & $\begin{array}{l}\text { In our company, we aspire to a high } \\
\text { degree of interfunctional information } \\
\text { exchange. }\end{array}$ & .901 & & \\
\hline \multirow[t]{3}{*}{ Financial performance } & $\begin{array}{l}\text { Overall profit levels achieved } \\
\text { compared to competitors (EBIT) }\end{array}$ & .881 & .91 & .78 \\
\hline & $\begin{array}{l}\text { Return on investment compared to } \\
\text { competitors (ROI) }\end{array}$ & .910 & & \\
\hline & $\begin{array}{l}\text { Profit margins compared to } \\
\text { competitors }\end{array}$ & .863 & & \\
\hline \multirow[t]{3}{*}{ Market performance } & $\begin{array}{l}\text { Market share compared to } \\
\text { competitors. }\end{array}$ & .879 & .83 & .62 \\
\hline & $\begin{array}{l}\text { Sales volume achieved compared to } \\
\text { competitors. }\end{array}$ & .896 & & \\
\hline & $\begin{array}{l}\text { Levels of customer satisfaction } \\
\text { compared to competitors }\end{array}$ & .546 & & \\
\hline
\end{tabular}

Source: Authors Calculation

Additionally all items of the single measures loaded significantly on their underlying factors (all loadings were higher than .50 with significant $t$ values). Discriminant validity was assessed with the pair-wise squared correlations comparison with the variance extracted estimates for the dimensions making up each 
possible pair. In every case the Fornell-Larcker criteria was met which means that the variance extracted estimates exceeded the square of the correlation between the factors making up each pair.

\section{RESULTS}

In the second stage of the research, the hypotheses were tested with multivariate (Tables 3 and 4) regression analysis where the single constructs of customer and employee business culture were treated as predictor variables and market and financial performance as dependent variables. To obtain more favourable number of parameters to be estimated, we conducted an additional simplification from 23 indicators to final 8 factors computed according to CFA. This was achieved by averaging the corresponding indicators leading to a single composite factor. The final regression models are presented in tables 3 and 4 .

TABLE 3- Regression model 1: Customer oriented business culture constructs impact on market and financial performance

\begin{tabular}{|c|c|c|c|c|}
\hline & Beta & $\mathbf{t}$ & p values & $\begin{array}{l}\text { Variance } \\
\text { inflation } \\
\text { factor }\end{array}$ \\
\hline (Constant) & & 9.749 & $\mathrm{p}<.01$ & \\
\hline Customer orientation & .210 & 3.871 & $\mathrm{p}<.01$ & 1.500 \\
\hline Competitor orientation & .129 & 2.376 & $\mathrm{p}<.05$ & 1.502 \\
\hline Interfunctional coordination & .017 & .327 & n.s & 1.375 \\
\hline \multicolumn{5}{|c|}{ Dependent variable: market performance; $\mathrm{R}^{2}=.099 ; \mathrm{p}<.01 ;$ Durbin-Watson coefficient $=1,96$} \\
\hline & Beta & $\mathbf{t}$ & p values & $\begin{array}{c}\text { Variance } \\
\text { inflation } \\
\text { factor }\end{array}$ \\
\hline (Constant) & & 7.290 & $\mathrm{p}<.01$ & \\
\hline Customer orientation & .282 & 5.219 & $\mathrm{p}<.01$ & 1.500 \\
\hline Competitor orientation & .091 & 1.688 & $\mathrm{p}<.10$ & 1.502 \\
\hline Interfunctional coordination & -.025 & -.480 & n.s & 1.375 \\
\hline $\begin{array}{l}\text { Dependent variable: financial } \\
\text { coefficient }=1,90\end{array}$ & performance; & $\mathrm{R}^{2}=.107$ & $\mathrm{p}<.01 ;$ & Durbin-Watson \\
\hline
\end{tabular}

Source: Authors Calculation

As can be seen from table 3 the majority of impacts are positive and statistically 
significant. Costumer orientation and competitor orientation significantly positively impacts market performance and financial performance. In both models interfunctional coordination link to both performances is non-significant. Variance inflation factors (VIF) in both models are low (under 5) suggesting that there is no problem with multicolinearity. According to that we can give support to hypotheses $\mathrm{H} 1$ and $\mathrm{H} 2$.

TABLE 4- Regression model 2: Employee oriented business culture constructs impact on market and financial performance

\begin{tabular}{|c|c|c|c|c|}
\hline & Beta & $\mathbf{t}$ & p values & Varinace inflation factor \\
\hline (Constant) & & 13.011 & $\mathrm{p}<.01$ & \\
\hline Employee orientation & .052 & .798 & n.s & 2.025 \\
\hline Competitor orientation (on the employee market) & -.025 & -.460 & n.s & 1.420 \\
\hline Interfunctional coordination on internal markets & .142 & 2.230 & $\mathrm{p}<.05$ & 1.918 \\
\hline \multicolumn{5}{|c|}{ Dependent variable: market performance; $\mathrm{R}^{2}=.024 ; \mathrm{p}<.01$; Durbin-Watson coefficient $=2.10$} \\
\hline & Beta & $\mathbf{t}$ & p values & Varinace inflation factor \\
\hline (Constant) & & 10.643 & $\mathrm{p}<.01$ & \\
\hline Employee orientation & .221 & 3.410 & $\mathrm{p}<.01$ & 2.025 \\
\hline Competitor orientation (on the employee market) & -.074 & -1.369 & n.s & 1.420 \\
\hline Interfunctional coordination on internal markets & .035 & .558 & n.s & 1.918 \\
\hline \multicolumn{5}{|c|}{ Dependent variable: financial performance; $\mathrm{R}^{2}=.047 ; \mathrm{p}<.01 ;$ Durbin-Watson coefficient $=1.90$} \\
\hline
\end{tabular}

Source: Authors Calculation

Contrary to the table 3 , the table 4 suggests that the employee oriented culture does not impact market and financial performance. In this case the majority of impacts are not statistically significant. Only interfunctional coordination on internal markets statistically significantly positively impacts market performance and employee orientation significantly positively impacts financial performance. All other relationships are non-significant. Variance inflation factors (VIF) in both models once again shows that there is no problem with multicolinearity. According to the research results we reject hypotheses $\mathrm{H} 3$ and $\mathrm{H} 4$.

\section{CONCLUSIONS}

The presented research examined enterprise culture as one of the enterprise's key success factors as thought and perceived by many models of integral man- 
agement and also by MER Model of Integral Management (Belak, 2010), which was the theoretical basis of various researches as described in the present article also on topic of the model's selected enterprise's key success factors as enterprise ethics, and culture. Our research cognitions show that enterprises, which are more customer (externally) oriented, show better market performance as well as better financial performance. The cognitions also show that more employee (internally) oriented enterprises, show positive impact to their market as well as to their financial performance. However, the question persists, why competitor orientation (on the employee market), and interfunctional coordination on both (internal and external) markets do not influence market and financial performance. Direct measurement of competitor orientation and interfunctional coordination on internal markets impact on both types of performances can be one reason for non-existent relationships, since one can define possible mediators through which the employee oriented business culture indirectly influences enterprise performance. Customer oriented business culture, innovation orientation, social responsible behaviour, and customer relationship orientation can only be some of the possible mediating variables.

The herein presented research as well as other various research cognitions described earlier in this article give us the important owners' and managers' implication that in terms of enterprise long term success the owners and managers of the enterprises have to consider enterprise culture (one of the important constitutional elements of business ethics) as one of the enterprise's key success factors, which must not be neglected in any way. To achieve the enterprise success the owners with their managers have to assure such conditions (internally as well as externally) which would foster the enterprise growth and development, its effectiveness and efficiency. On the other hand the conditions fostering enterprise's effectiveness and efficiency should consider the enterprise's success based on the principles of business ethics, which is only possible way for an enterprise to attain the status of credible partner in the environment of such enterprise functioning.

As an effort to address a complex phenomenon, this study is subject to several limitations. Our cognitions partly confirm the theoretical argument that 
enterprise long term success can be ensured only by practicing the external (effectiveness) as well as internal (efficiency) orientation of enterprise. Therefore, the further research should be done to in-depth explore the impact of both orientations (external and internal) to the enterprises' performance. In addition the research should explore also the impact of the social responsible behaviour (in relation to external and internal orientation) of the enterprises on their performance. Also other possible other mediators should be included in the culture - performance relationship models. The fact that the main respondents for this study were managers' from one function and not both managers and employees can provide unreliable results. Further, because of the regression design of the study, common method variance can potentially have an effect on the research findings, but is unlikely to occur since the factor analysis presented, resulted in a multi-factor solution, in which one factor did not accounted for majority of the variance. Finally, the results of the study are context-specific and relate to developing country in transition.

\section{REFERENCES}

Atuahene-Gima, K., Slater, S. F., Olson, E. M. 2005. The contingent value of responsive and proactive market orientations for new product program performance. The Journal of Product Innovation Management 22: 464-482.

Baker W. E., and J. M. Sinkula. 2005. Market orientation and the new product paradox. The Journal of Product Innovation Management 22 (6): 483502 .

Berry, L. L. 1981. The employee as a customer. Journal of Retail Banking 3: $33-44$.

Belak, J. 2009. Business Ethics Implementation at Different Stages of the Enterprise Life Cycle. Maribor: MER Publishing House.

Belak, J., and M. Mulej. 2009. Enterprise ethical climate changes over life cycle stages. Kybernetes: : The International Journal of Systems \& Cybernetics 38 (7/8): 1377-1398.

Belak, J., Duh, M., Mulej, M., and T. Štrukelj. 2010. Requisitely holistic 
ethics planning as pre-condition for enterprise ethical behavior. Kybernetes: The International Journal of Systems \& Cybernetics 39 (1): 19-36.

Belak, J. 2010. Integralni management - MER model. Maribor: MER Evrocenter.

Belak, J., and B. Milfelner. 2011. Informal and formal institutional measures of business ethics implementation at different stages of enterprise life cycle. Acta Polytechnica Hungarica 8 (1): 105-122.

Cameron K., and R. Quinn. 1999. Diagnosing and changing organizational culture: Based on the competing values framework. New York, NY: AddisonWesley.

Cullen, J. B., Parboteeah, K. P. and B. Victor. 2003. The Effects of Ethical Climate on Organizational Commitment: A Two-Study Analysis. Journal of Business Ethics 46 (2): 127-141.

Deal T., and A. A. Kennedy. 1982. Corporate cultures: The Rites and Rituals of Corporate Life. Reading. MA: Addison-Wesley.

Duh, M., Belak, J., and B. Milfelner. 2010. Core Values, Culture and Ethical Climate as Constitutional Elements of Ethical Behavior: Exploring Differences between Family and Non-Family Enterprises. Journal of Business Ethics 97 (3): 473-489.

Duh, M., and J. Belak. 2009. The influence of a family on ethical behaviour of a family enterprise. Acta Polytechnica Hungarica 6 (3): 35-56.

Duh, M., Tominc, P., and M. Rebernik. 2009. The importance of family enterprises in transition economies : Is it overestimated?. East. Europ. econ. 47 (6), 22-42.

Fornell, C., and D.F. Larcker. 1981. Evaluating structural equation models with unobservable variables and measurement error. Journal of Marketing Research 18: 39-50.

Gray, J. H., Densten, I.L., and J. C. Sarros. 2003. A matter of size: does organizational culture predict job satisfaction in small organizations? Journal of Occupational and Organizational Psychology 70: 219-240.

Gounaris, S. P. 2006. Internal-market orientation and its measurement. Journal of Business Research 59: 432-448. 
Hofstede G. J. 1983. The cultural relativity of organizational practices and theories. Journal of International Business Studies 14 (2): 75-86.

Hofstede G. J., Neuijen B., Ohayv D. D., and G. Sanders. 1990. Measuring organizational cultures: A qualitative and qantitative study across twenty cases. Administrative Science Quaterly 35 (2): 286-316.

Hofstede G. 1998a. Attitudes, values and organizational culture: Disentangling the concepts. Organization Studies 19 (3): 477-492.

Hofstede G. 1998b. Identifying organizational subcultures: An empirical aproach. Journal of Management Studies 35 (1): 1-12.

Hofstede G. J. (2000). Organizational culture: siren or sea cow?. Strategic Change 9: $135-137$.

Huczynski A., and D. Buchanan. 2007. Organizational Behaviour. Essex: Pearson Education Limited.

Igo T., and M. Skitmore. 2006. Diagnosing the organizational culture of an Australian engineering consultancy using the competing values framework. Construction Innovation 6: 121-139.

Kaptein, M. and S. Avelino. 2005. Measuring corporate integrity: A surveybased approach. Journal of Business Ethics 5 (1): 45-54.

De Vries, K. M. 1993. The dynamics of family controlled firms: The good and the bad news', Organizational Dynamics 21 (3): 59-71.

Kohli, A. K., and B. J. Jaworski. 1990. Market orientation: the construct, research propositions, and managerial implications. Journal of Marketing 54 (2): $1-18$.

Lings, I. N. 2004. Internal market orientation. Construct and consequences. Journal of Business Research 57: 405-413.

Lings I.N. and G. E. Greenley. 2009. The impact of internal and external market orientations on firm performance. Journal of Strategic Marketing 17 (1): 41-53.

Narver, J. C. and S.F. Slater. 1990. The effect of a market orientation on business performance. Journal of Marketing 54: 20-35.

Narver, J. C., Slater S. F., and D. L. MacLachlan. 2004. Responsive and proactive market orientation and new-product success. Journal of Product 
Innovation Managament 21: 334-347.

Ouchi W. 1981. Theory Z: how American business can meet the Japanese challenge. Reading, MA: Addison-Wesley.

Sathe, V. 1984. Implications of corporate culture: a manager's guide to action. Organizational Dynamics 12 (2): 4-23.

Schein E. H. 1983. The role of the founder in creating organizational culture. Organizational Dynamics 13 (1): 13-28.

Schein E. H. 1985. Organizational Cultures and Leadership. San Francisco: Jossey-Bass.

Schein E. H. 1992. Organizational culture and leadership. San Francisco: Jossey-Bass.

Schwartz H., and S. Davis. 1981. Matching Corporate Culture and Business Strategy", Organizational Dynamics 10: 30-48.

Thommen J.-P. 2002. Management und Organisation. Zürich: Versus Verlag. Thommen J.-P. 2003. Glaubwürdigkeit und Corporate Governance, 2. vollständig überarbeitete Auflage. Zürich: Versus Verlag.

Vallejo, M. C. 2008. Is the culture of family firms really different? A valuebased model for its survival through generations. Journal of Business Ethics 81 (2): 261-279.

Victor, B. and B. J. Cullen. 1988. The organizational bases of ethical work climates. Administrative Science Quarterly 33 (1): 101-125.

Webster, C. 1995. Marketing culture and marketing effectiviness in service firms. Journal of Services Marketing 9 (2): 6-21.

Werner, S., Praxedes, M. and H. Kim. 2007. The reporting of nonresponse analyses in survey research. Organizational Research Methods 10: 287-95.

Ženko, Z., and J. Marn (2006). Systemic approach to innovations - standards vs software. Kybernetes 35 (7/8): 1100-1108. 


\section{INTEGRALNI PRISTUP KULTURI PODUZETNIŠTVA KAO JEDNOM OD KLJUČNIH FAKTORA USPJEHA U PODUZETNIŠTVU}

Sažetak:

Mnogi priznati znanstvenici i istraživači smatraju kulturu poduzetništva jednom od osnovnih odrednica poduzetničkog uspjeha. Ovaj članak pokazuje rezultate istraživanja o utjecaju kulture poduzetništva na uspjeh promatranih poduzeća. Istražuje poduzetničku kulturu usmjerenu na klijenta i zaposlenika te njen utjecaj na tržište i financijsku performansu poduzé́a. Rezultati ukazuju na to da poduzé́a koja su usmjerenija na klijenta (eksterno), pokazuju bolje tržišne kao i financijske performanse. Rezultati također pokazuju da poduzé́a orijentiranija na zaposlenike (interno) pokazuju pozitivan utjecaj na tržište i na vlastite financijske performanse.

Ključne riječi: integralni management, temeljne poduzetničke vrijednosti, organizacijska kultura i klima, uspjeh poduzeća, ključni faktori uspjeha poduzeća 